\title{
Citizen Support for Increasing the Responsibilities of Local Government in European Countries: A Comparative Analysis
}

\author{
Keith BAKer, SteVen VAN DE WALle \& Chris Skelcher
}

\begin{abstract}
The transfer of responsibilities from central to local government has often been justified on the grounds of efficiency and democracy under the principle of subsidiarity. The existing models for mapping local government power in Europe, however, are often insufficiently detailed to allow an in-depth comparison, and little is known about the level of citizen support for increasing the responsibilities of local government. This paper attempts to expand this knowledge base by using financial local government data and opinion data from the European Values Study to analyse these questions. It relates the level of local government responsibilities in Europe to the level of citizen support for increasing local government responsibilities. These findings are then used to develop a research agenda on local government measurement, and to reflect on the difficulties facing the European comparative local government researcher.
\end{abstract}

KEYWORDS: • comparative local government • citizen attitudes • local government power $\bullet$ decentralisation $\bullet$ local government spending

CorRespondence AdDress: Keith Baker, Ph. D., Department of Politics and International Relations, School of Social Sciences, University of Southampton, SO17 1BJ, UK, email: k.baker@soton.ac.uk. Steven Van De Walle, Ph. D., Department of Public Administration, Faculty of Social Sciences, Erasmus University Rotterdam, PO Box 1738, 3000 DR Rotterdam, The Netherlands, email: vandewalle@fsw.eur.nl. Chris Skelcher, Ph. D., Professor of Public Governance, Institute of Local Government Studies, University of Birmingham, Edgbaston, Birmingham, B15 2TT, UK, email: c.k.skelcher@bham.ac.uk.

DOI 10.4335/9.1.1-21(2011)

ISSN 1581-5374 Print/1855-363X Online (C) 2011 Lex localis (Maribor, Graz, Trieste, Split)

Available online at http://pub.lex-localis.info. 
The Council of Europe's European Charter of Local Self-Government (1985) proclaims that citizen participation is an essential democratic principle, and that it can be most directly exercised at the local level. The local level can also provide the administration that is both effective and close to the citizens (Preamble). As such, the Charter promotes the principle of subsidiarity, which in this context means that 'Public responsibilities shall generally be exercised, in preference, by those authorities that are closest to the citizen. Allocation of responsibility to another authority should weigh up the extent and nature of the task and requirements of efficiency and economy' (Article 4§3).The Charter's philosophy is that the decentralisation of power and strong local government are essentially democratic. This subsidiarity requires a careful assessment of whether there is a necessity to transfer powers to higher authorities. Economic writers do not generally consider the local level as 'superior', but they instead speak about the most appropriate level to perform public tasks. They explore ways to determine the optimal level of paying for, deciding on, and delivering public services (Oates, 1972; Tiebout, 1965).

Statements on subsidiarity are frequently interpreted in a way that suggests that transferring powers from the central to the local level is generally a good thing. Or in other words, that the local level is more often than not considered a more appropriate level for designing and delivering policy than the central level. Local government has been traditionally equated with liberty, and seen as a bulwark against centralised power (King, 1995). Recent decades have seen a decline in respect for authority, especially when this authority is exercised centrally rather than locally (Inglehart, 1997). Citizens have been found to feel greater political competence and efficacy at the local level than at the central level (Almond \& Verba, 1965), and they often feel a greater attachment to the local level (Vetter, 2007). Thanks to its closeness to citizens and due to the relative openness of its decision-making, local government is seen as very able to take citizens' concerns and preferences into account (e.g., Sharpe, 1970). As a result, the local level is sometimes considered to be able to create legitimacy for government in general (Vetter, 2002; 2007).

There appears to be an increasing and continuing (also academically disputed) trend to decentralise authority to local government (Proeller, 2006). This decentralisation occurs because it is believed that increasing the responsibilities of local government has a positive effect on people's lives. It leads to reconnecting citizens with government and politics. Yet, the empirical support for these changes is surprisingly limited. In this paper, we explore two related issues:

(1) How much responsibility does local government actually have? 
(2) Do citizens actually support increasing the responsibility of local authorities?

To address these issues, the paper first attempts to categorise European local governments in terms of their characteristics, powers and competences, and it illustrates European differences by using financial and fiscal data. This approach is very different from the quasi-historical methods that have dominated previous attempts to classify local government (see, for example, Page \& Goldsmith, 1987, or Hesse \& Sharpe, 1991). The use of fiscal data allows us to focus on the actual operations of local government rather than on its legal status or its historical origins (Lidström, 1998). We then refer to the European Values Study to map citizen support for increasing the power of local authorities in a series of European countries. These two sets of indicators are then compared to analyse whether the extent of local government responsibilities in a country determines citizen support for increasing them. Thus, we are able to determine whether or not the subsidiarity principle enjoys popular support across Europe. After demonstrating the value of using opinion and attitudinal data in addressing subsidiarity, the paper proceeds to outline an agenda for a more nuanced approach to comparative political research. This agenda seeks to switch the focus of analysis from local government per se to the specific functions or activities performed by local government, and to the understanding citizens have of what local government could or should be doing. This would allow for detailed comparisons across different countries, and therefore, the paper serves a wider purpose in identifying a means by which comparative political research may be theoretically and practically advanced.

\section{$2 \quad$ More Power for Local Authorities?}

The case for or against decentralisation can be made from different perspectives, including efficiency, equity, and democratic governance considerations (Wolman, 1990). Different visions on the division of roles between central and local levels exist (Brans, 1992). They can be generally divided into two main perspectives. Kjellberg (1985) distinguishes between an autonomous model (where the local levels operate relatively unimpeded by the central level) and an integration model (where local and central levels are integrated, and the division of tasks is functional and pragmatic). The empirical evidence on the benefits of decentralisation is mixed, and there is often a large divergence between the theory and the empirical reality (Wolman, 1995). It has been argued that local delivery of public services has a number of advantages. One advantage is that local delivery allows for a better identification of citizens' preferences, resulting in more effective delivery and less waste. Delivering at a more centralised level may lead to an imperfect match between the services that are being delivered and those services that citizens actually want. The short distance between providers and clients may also improve responsiveness, thus making lines of accountability shorter. In this way, it becomes easier for citizens to exert influence. Finally, strong local authorities may contribute to both citizens' identification with the local level and the pride in their community. 
For these reasons, it could be hypothesised that in the countries where local government power is limited, citizens will be in favour of the transfer of power to local government. Such a transfer potentially strengthens both accountability relations and the way in which government outputs are valued. However, an alternative argument could be made that in the regions where local governments have abused their powers, or where local government has been particularly nepotistic or corrupt, citizens will be in favour of taking responsibilities away from the local level, or they will have them executed at a higher level (in this case, in a more effective and accountable manner).

\section{Frameworks for Understanding the Responsibilities of Local Government}

Certain government functions are carried out by local government as opposed to central government (Bennett, 1993). Local government has many different responsibilities, and they vary substantially across Europe. For this reason, coming up with good indicators for local government powers is not straightforward. Several attempts have been made in the past to develop typologies of local government and local government responsibility in European countries. Responsibility can be understood as referring to the ability of local government to exercise discretion within the different functions that are allotted to local government (Norton, 1991). However, assessing the level of responsibility that is afforded to local government throughout Europe is a particularly difficult task, given the diversity of systems that exist throughout Europe (Norton, 1991; Elander, 1991). Local government systems have developed in quite diverging ways in European countries (Wollmann, 2000). This diversity can be illustrated by considering a simple example. In the UK, primary health care is provided by the central government (through a multitude of quasi-private entities), whereas social and welfare services are provided by local authorities. This can be compared to Finland where both health care and social services are administered at the municipal level (Haveri, 2006).

There are a variety of approaches to understanding the responsibilities of local government, and there is a need for comprehensive and up-to-date typologies (Wolman, 2008). Without such typologies, it is difficult to generalise beyond national case studies. Several attempts have been made to develop useful typologies. The two most popular ones are the Page and Goldsmith (1987) framework, and Hesse and Sharpe's historically-based approach (1991). These frameworks offer different attempts to classify local government systems in respect of the functions and the degree of autonomy that is allocated to local government within the system of government (Denters \& Rose, 2005). The Page and Goldsmith (1987) framework divides Western Europe into two categories: the northern countries and the southern countries. The north is deemed to consist of the United Kingdom (UK) and Ireland, Germany and Austria, the Netherlands and the Scandinavian countries, while the south is seen as France, Belgium, Italy, Greece, Spain, and Portugal. In the north, 
local government has developed in response to demands from the population, and, as such, local government has a substantial range of responsibilities which it exercises independently of the central state (Kjellberg, 1995). This is opposed to the southern group of countries in which the state is more centralised (Kuhlmann, 2006), and local government has relatively few responsibilities.

Although the simplicity of the Page and Goldsmith (1987) framework is a considerable attraction (see John, 2001), this is also a source of considerable weakness in that the framework does not describe the nuances of individual countries particularly well.

In an effort to overcome these problems, Hesse and Sharpe (1991) argue that Europe does have a southern group of countries in which local government has limited responsibilities due to a highly centralised state (Norton, 1993). Hesse and Sharpe then proceed to separate out Page and Goldsmith's (1987) northern countries into a middle or central European group of countries that include Germany, the Netherlands, Austria, and the Scandinavian countries. They locate Britain and Ireland in Anglo-Saxon nations that operate on the ultra vires principle (Norton, 1993). This refers to the notion that local government may only exercise those responsibilities that have been granted to it by central government. Although this framework is more subtle than Page and Goldsmith's approach, Denters and Rose (2005a: 11) argue that Hesse and Sharpe pay insufficient attention to the constitutional structure of different countries, a position that Page (1991) has some sympathy with. For Denters and Rose, it makes little sense to conflate the federal system of Germany with the unitary model of Sweden because there is substantially more variation in the nature, size and responsibilities of local governments within Germany.

It is also possible to identify two further problems with the Page/Goldsmith (1987) and Hesse/ Sharpe (1991) frameworks in that the range of countries that they examine within Europe is comparatively limited and the frameworks are rather old. Page/Goldsmith and Hesse/Sharpe tend to focus on the countries that are commonly understood as 'Western'. This leads to the exclusion of the former Soviet republics such as Estonia, Lithuania, and the Russian Federation that are considered part of Europe and are represented in the Council of Europe. The age of frameworks themselves is also a problem in that they do not take into account recent developments in local government. For example, Borraz and Le Galès (2005) point out that the French central government (the archetypical centralised state) has decentralised much of its power to local authorities. Wayenberg (2006: 49) also notes that many central governments seek to enlist their [subordinate] local authorities as partners, and as such, the boundaries that mark the responsibilities of local government have started to dissolve.

Therefore, it is possible to conclude that the utility of wider analytical frameworks is of limited use in understanding the powers of local government in Europe because 
they are invariably awkward and insensitive to detail (Lidström, 1998). Owing to this, we have opted to return to first principles, and we consider the systems of each European nation independently without relying on the pre-existing frameworks as a means of structuring the analysis.

\subsection{Fiscal Measures of Different Levels of Local Government Responsibility}

The previous discussion has shown that the attempt to develop typologies of local government in Europe is problematic due to a wide variety of responsibilities afforded to local government within different systems. As such, an attempt to develop a measure of specific responsibilities afforded to local government is extremely difficult. This problem can be overcome by using financial metrics because finance is one of the few areas where detailed information is available to compare the power of a large number of national local government systems. It needs to be acknowledged, though, that this method may also cause a few problems.

Financial measures are generally used to measure the size of local government (Blair, 1991). This technique has become widely accepted (Sharpe, 1988). It can be used to proxy the level of responsibility that is afforded to local government. If local government is afforded a significant level of responsibility within a system, it will be responsible for the delivery of more functions, and it will thus consume more financial resources. Elander (1991) argues that caution is needed because such measures do not take into account the relative efficiency of local government, and an authority that spends a great deal of money may simply be inefficient. However, local government in Europe has been subject to a vast number of reforms since the mid-1980s, which have been inspired by the New Public Management (Denters and Rose, 2005b; Proeller, 2006 \& Wayenberg, 2006). They have placed efficiency at the heart of local government management (Pollitt, 2003). Therefore, the caricature of inefficient local government is rather outdated, and we argue that the level of expenditure by local government is a reflection of the responsibilities that it is tasked with.

Although financial indicators offer an effective way of examining the different levels of responsibility ceded to local government, reliance on a single measure would be extremely crude. As such, we use three local government expenditure indicators: local government expenditure relative to the GDP, reflecting the absolute importance of local government; local government expenditure as a percentage of general government expenditure, reflecting relative importance; and the revenue raising capacity of local government, an indicator that focuses on the income side rather than on the expenditure side. In this section, we use Council of Europe statistics to measure the level of responsibility afforded to local government in Europe. While these statistics may not be very recent for some countries, the statistics represent some of the most recent data that is available for many countries 
in Europe. Figure 1 shows local government spending in European countries as a percentage of a country's GDP to measure the absolute impact, and as a percentage of general government expenditure to measure the relative weight of local government in a country.

Figure 1: Local government spending as a percentage of GDP and as a percentage of general government expenditure

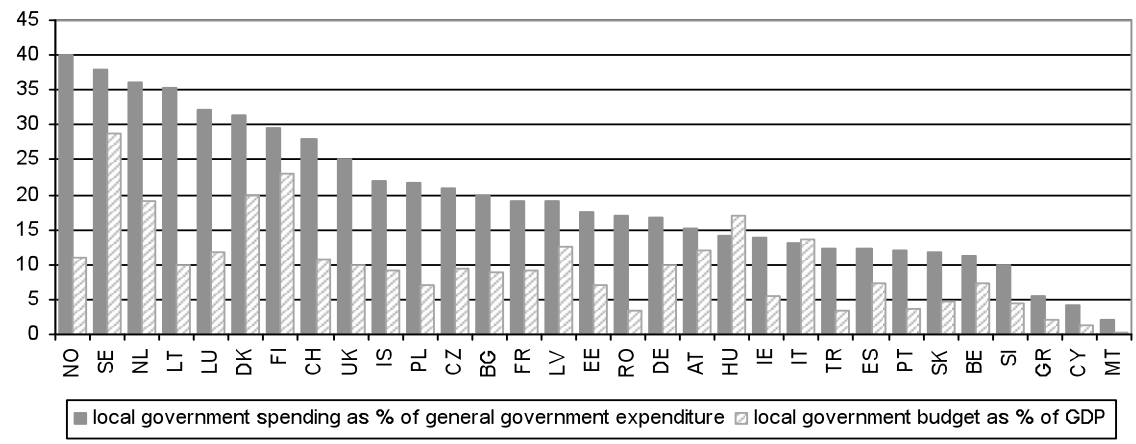

Source: Council of Europe (2000), The financial resources of local authorities in relation to their responsibilities: a litmus test for subsidiarity. 4th General Report on Political Monitoring of the Implementation of the European Charter of Local Self-Government.

In the countries such as Sweden, Finland, and Denmark, local government budgets (as a percentage of the GDP) are quite large and more than double those in other European countries. When we look at local government expenditure in relation to general government expenditure, this expenditure is higher in Northern European and Scandinavian countries. This finding seems to empiri cally support the Page and Goldsmith (1987) framework that there is a distinct group of 'Northern' countries in which local government has a comparatively high status.

These statistics, of course, do not tell us how much of this budget comes from specific transfers from national government. However, if central government massively subsidises local government, this does not undermine the central argument because local government is ultimately responsible for the disposal of these resources. The final indicator that we are going to use is the weight of local taxes in the local budget. 


\section{Figure 2: $\quad$ Weight of local taxes in local budget}

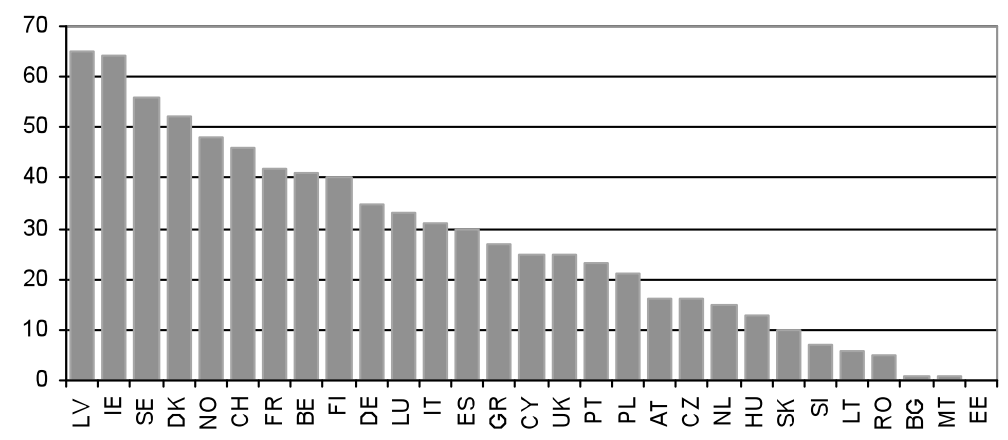

Source: Council of Europe (2000), The financial resources of local authorities in relation to their responsibilities: a litmus test for subsidiarity. 4th General Report on Political Monitoring of the Implementation of the European Charter of Local Self-Government.

Again, as Figure 2 shows, there is quite some variation across European countries. The weight of local taxes in the local budget ranges from over $60 \%$ in Latvia and Ireland to marginal percentages in Estonia, Malta, and Bulgaria.

However, it is necessary to inject a note of caution as to the data because some of the Council of Europe statistics we use are rather old. Despite the fact that the publication we use was published in 2000, most of the financial data in the report refers to the situation in the early or mid-1990s. Secondly, there is often a very thin line between levels of local government with shared responsibilities and many special decision-making and funding schemes, which makes it difficult to distinguish between local and regional levels when using official statistics. Relying on a single measure of financial and fiscal decentralisation ignores many of the complexities of local government financing. Expenditure autonomy is not necessarily matched with revenue raising autonomy, and mere financial measures say little about decision-making discretion (Stegarescu, 2005).

\subsection{Support for Increasing the Responsibilities of Local Government}

In this section, we test the second main of our argument to see if citizens support increasing the responsibilities of local authorities. The empirical material is extremely limited. We have unearthed one indicator that has, to our knowledge, not been used before in comparative local government research. In 1999, the questionnaire of the European Values Study, an international sociological survey on value change in society, contained a question on the extent of local government powers (Halman, 2001). In a number of European countries, citizens were asked whether they thought local authorities should be allowed to exercise greater powers, 
i.e., greater levels of responsibility. More specifically, they were asked whether they would consider this to be a good thing or a bad thing, or whether they did not care. The results are shown in Table 1.

\section{Table 1: More power to local authorities is a good thing?}

\begin{tabular}{|c|c|c|c|c|c|c|}
\hline & & Good & Don'tmind & $\mathrm{Bad}$ & NA/DK & $\mathrm{N}$ \\
\hline MT & Malta & 67.5 & 15.2 & 17.3 & 0.0 & 1,001 \\
\hline $\mathrm{CZ}$ & $\begin{array}{l}\text { Czech } \\
\text { Republic }\end{array}$ & 63.9 & 16.5 & 10.9 & 8.7 & 1,908 \\
\hline SK & Slovakia & 59.7 & 16.2 & 5.0 & 19.1 & 1,326 \\
\hline RO & Romania & 59.6 & 12.3 & 12.5 & 15.6 & 1,146 \\
\hline TR & Turkey* & 56.7 & 18.7 & 20.6 & 4.0 & 1,206 \\
\hline PT & Portugal & 52.9 & 29.0 & 10.5 & 7.6 & 1,000 \\
\hline FR & France & 48.7 & 30.6 & 13.9 & 6.8 & 1,615 \\
\hline GR & Greece & 48.7 & 38.9 & 8.1 & 4.3 & 1,142 \\
\hline PL & Poland & 46.7 & 27.1 & 11.7 & 14.5 & 1,094 \\
\hline RU & Russian Fed. & 44.9 & 25.6 & 12.7 & 16.8 & 2,500 \\
\hline EE & Estonia & 44.0 & 27.5 & 13.3 & 15.2 & 1,005 \\
\hline IE & Ireland & 43.5 & 26.2 & 22.7 & 7.6 & 1,012 \\
\hline IS & Iceland & 43.3 & 29.4 & 15.2 & 12.1 & 968 \\
\hline FI & Finland & 42.8 & 22.7 & 27.0 & 7.5 & 1,038 \\
\hline UA & Ukraine & 42.8 & 20.5 & 11.8 & 24.9 & 1,207 \\
\hline $\mathrm{DE}$ & Germany & 41.6 & 26.8 & 22.0 & 9.7 & 2,036 \\
\hline & $\begin{array}{l}\text { Northern } \\
\text { Ireland }\end{array}$ & 41.3 & 27.1 & 17.2 & 14.4 & 1,000 \\
\hline HR & Croatia & 40.0 & 18.5 & 28.4 & 13.0 & 1,004 \\
\hline LT & Lithuania & 40.0 & 32.4 & 7.6 & 20.0 & 1,017 \\
\hline BG & Bulgaria & 39.1 & 27.1 & 10.2 & 23.6 & 1,000 \\
\hline IT & Italy & 38.5 & 37.4 & 15.6 & 8.6 & 2,000 \\
\hline SI & Slovenia & 38.5 & 28.6 & 25.4 & 7.5 & 1,006 \\
\hline DK & Denmark & 37.3 & 16.1 & 31.6 & 15.0 & 1,023 \\
\hline ES & Spain* & 35.6 & 28.2 & 24.4 & 11.8 & 1,200 \\
\hline LV & Latvia & 34.9 & 22.1 & 26.5 & 16.5 & 1,013 \\
\hline AT & Austria & 34.2 & 24.6 & 30.7 & 10.4 & 1,522 \\
\hline GB & $\begin{array}{l}\text { Great } \\
\text { Britain }\end{array}$ & 34.2 & 28.9 & 27.8 & 9.2 & 994 \\
\hline LU & Luxembourg & 33.1 & 26.0 & 28.1 & 12.8 & 1,212 \\
\hline SE & Sweden & 32.1 & 20.5 & 38.7 & 8.7 & 1,013 \\
\hline VE & Belgium & 29.6 & 31.9 & 30.5 & 8.1 & 1,911 \\
\hline BY & Belarus & 27.2 & 36.5 & 20.4 & 15.9 & 1,000 \\
\hline NL & Netherlands & 25.6 & 21.9 & 50.8 & 1.7 & 1,001 \\
\hline HU & Hungary & 22.7 & 22.3 & 47.4 & 7.6 & 1,000 \\
\hline
\end{tabular}

Source: European Values Study (1999). N is approx. 1,000 in every country. 'Here is a list of various changes in our way of life that might take place in the near future. Please tell me for each one, if it were to happen whether you think it would be a good thing, a bad thing, or don't you mind? More power to local authorities'. *Question only asked for selection of respondents in Spain and Turkey. NA/DK= No answer/don't know.

There are considerable differences between countries: In Malta and the Czech Republic, two-thirds of the population think granting more power to local 
authorities to be a good idea, while this is just a quarter in Hungary and the Netherlands. In Central and Eastern European countries, the greatest number of proponents for increasing the responsibilities of local authorities can be found, with Hungary and Belarus as exceptions. In the Benelux, Sweden, and Great Britain, the level of support was much lower. For the UK, we have separate numbers for Great Britain and Northern Ireland, which reveals quite important differences, with more of the Northern Irish respondents in favour of increasing the responsibilities of local authorities. This difference may be explained in terms of a reaction to extensive supervision of local government in Northern Ireland by the UK Government during the period known as the 'Troubles' (1970s -1990s).

\section{$4 \quad$ Is Support for Increasing Local Government Responsibilities Related to the Level of Actual Responsibilities?}

In the previous sections, we have made an attempt at mapping the level of responsibility assumed by local government in European countries, and we have subsequently analysed whether citizens in these countries actually support the transfer of responsibility to local authorities. In Table 1, we can see that there are considerable differences in the level of support for increasing the responsibilities of local authorities. One explanation for the large differences between countries could be the actual level of responsibility held by local government in these countries. In other words, popular support for increased responsibilities could be higher in the countries where local authorities have a limited status. The countries where local governments are spending only a small percentage of a country's overall government expenditure could be considered as those with limited decentralisation.

In Figure 3, we correlate budgetary measures of local government responsibility and the survey results on support for increased responsibilities. This shows that the limited responsibility at the local level is not associated with higher support for increasing the local authority responsibilities. However, relatively high local government expenditures seem to dampen demand for more local government power, possibly because local government already has this power. 
Figure 3: Local government expenditure (relative to GGE) and preferences for more power

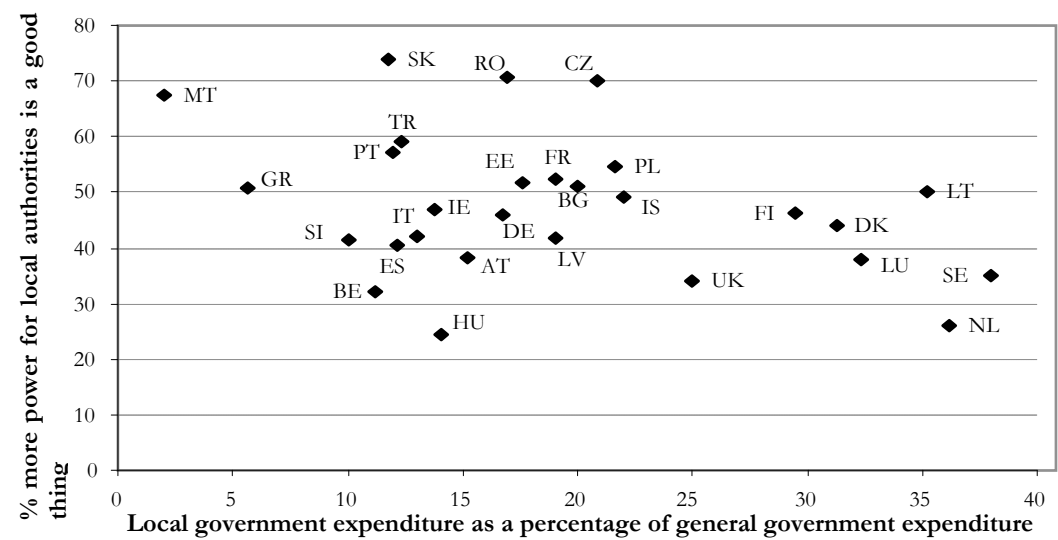

Source: Council of Europe (2000) and European Values Study (1999). Pearson correlation= -.352 (not significant). Attitude data for Great Britain are compared to financial data for the UK.

In Figure 4, local government expenditure relative to the GDP is compared to preferences for increasing the responsibilities of local authorities. This shows a considerable relationship between low levels of local government expenditures and the increase in the competencies of local government. However, the countries where increasing the responsibilities of authorities is considered a good thing are mostly Central and Eastern European countries. When we drop these countries from the analysis and only look at Western European countries, the relationship disappears.

Figure 4: Local government expenditure (relative to GDP) and preferences for more power

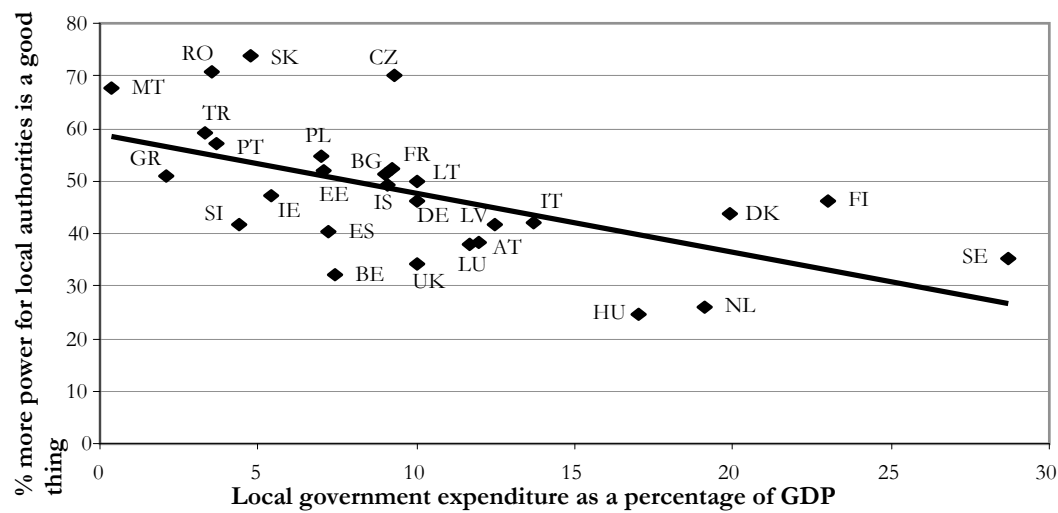

Source: Council of Europe (2000) and European Values Study (1999). Pearson correlation= -.582. Attitude data for Great Britain are compared to financial data for the UK. 
The final test results are shown in Figure 5 where we compare preferences for increased responsibility with the weight of local taxes in the local government budget. The hypothesis is that where a local government is allowed to raise its own revenue, it is likely to exercise a high level of discretion, thereby having a higher level of responsibility for the delivery of different functions. However, a high weight for local taxes in the budget does not mean that local government is strong vis-à-vis the central government because there are the European countries that get much of their budget from local taxes, yet they have a rather limited budget compared with that of central levels of government (e.g., Ireland and Belgium). The figure shows a small relationship between support for increasing the responsibilities of local authorities and the importance of local taxes, yet this relationship is only marginally significant. Again, if we consider only Western European countries, the relationship disappears.

Figure 5: Weight of local taxes in the local government budget and preferences for more power

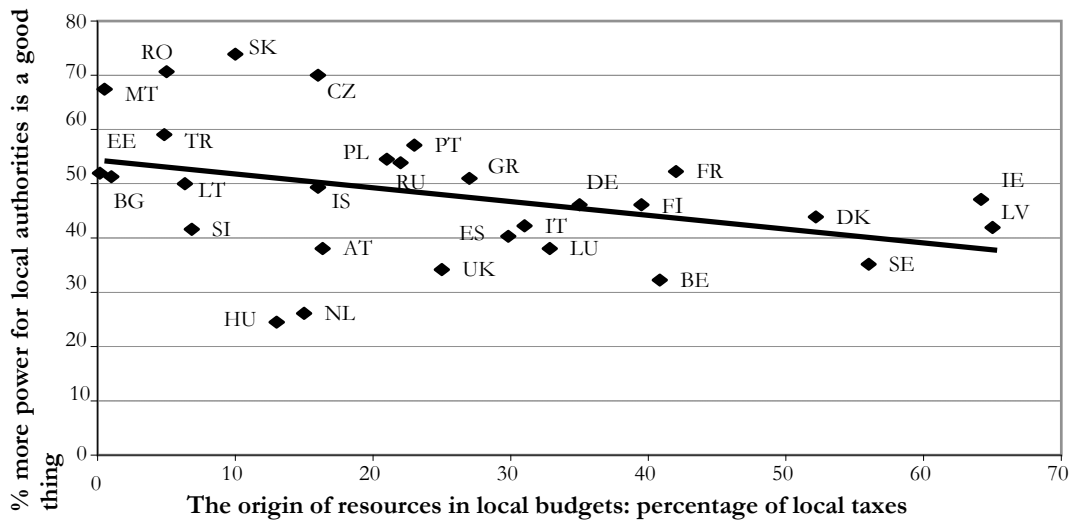

Source: Council of Europe 2000 and European Values Study 1999. Pearson correlation= $=.377$ (marginally significant). Attitude data for Great Britain are compared to financial data for the UK.

Therefore, the overall evidence indicates that the actual extent of local government responsibility cannot be considered as determining the levels of citizen support for increasing the responsibilities of local authorities. The preceding figures show that there are no clear regional patterns. There are some minor exceptions. In the analysis, the Nordic countries (Finland, Sweden, and Denmark) sometimes cluster together at one end of the figures. Southern countries are often found more or less together in the same location, but they generally remain more or less scattered throughout the figures. While the typologies presented earlier in this paper are very helpful in supporting the general debate and in explaining why the local government structures, developed in a certain way, do not explain the differences that exist 
between local governments in the countries within the same group [as Lidström (1998) has pointed out]

\section{Discussion: Measuring and Comparing Local Government Power}

In this paper, we analyse the relation between the responsibilities held by local government and the citizen support for increasing them. The findings show no perfect relation, and there are a number of regional patterns. The interpretation of the findings, however, is quite problematic. First, measuring and defining the different responsibilities of local government is quite complicated. Second, we can only assume that the citizens who in surveys require an increase in the number of specific responsibilities of local authorities actually demand such an increase. Third, the state of comparative local government research and the data make the drawing of firm conclusions premature.

\subsection{Can We Accurately Measure the Responsibilities of Local Government?}

The level of responsibility afforded to local government is hard to summarise in a single indicator. Local governments may receive a lot of money from central government without much spending discretion. They may have high budgets, yet no ability to levy local taxes at their discretion. In addition, many of the internationally comparable local government finance indicators are not kept fully up-to-date, or they compound indicators at different local and regional levels. In addition, a focus on financial indicators may neglect local government decision-making and political strengths.

\section{Defining Local Government}

Mapping of local government responsibilities and finances requires a good and uncontested delineation of local government. This should be fairly easy where local authorities are well-defined, and where there are few or no government levels between the municipal and central levels. The reality is that there is often a very thin line between levels of government resulting in a difficult distinction between local, supralocal, sub-regional, and regional levels. This situation is further complicated by shared responsibilities (Wayenberg, 2006), and by many special decision-making and funding schemes that make it difficult to distinguish between local and regional levels.

Due to the changing nature of governance at the local level, this situation is further complicated by the move towards multi-level, multi-actor arrangements, even in previously very centralised states such as France (Reigner, 2001). Multi-level and multi-actor governance arrangements with inter-municipal cooperation (Hulst \& van Montfort, 2007), horizontal and vertical partnerships, public-private cooperation, and the like make it very difficult to study local government as an isolated 
phenomenon, let alone measure it. As a result, the comparison becomes difficult due to a trend of transferring competences to single-purpose organisations in some countries, while other countries have multi-purpose local authorities. Therefore, the focus purely on traditional local government arrangements may risk ignoring many realities in the field such as alternative governance arrangements and intergovernmentalism (John, 2001; Goldsmith, 2005). While comparative local government has difficulties integrating diverse local governance arrangements into its models, local governance research still lacks a solid international comparative component.

\section{Multi-dimensionality of Local Government Responsibility}

The responsibilities, discretion, and functions of local government are multidimensional. The lack of good data has caused the authors to follow Sharpe (1988) in relying on financial indicators. However, large budgets may coincide with limited tax raising and spending discretion. Do local authorities have a general competence, making them responsible for all the matters that are of concern to a local community, or do they have a strictly defined list of competences? Merely counting or listing competences is meaningless unless we can also qualitatively assess these competences. Is a local authority with extensive powers in the fields of sports, culture, and education better able to exercise responsibility than the one without these powers, but with extensive planning and public works powers? Sometimes authorities have full responsibility, while in other cases, competences are merely delegated from the central level. When competences are shared, it is hard to assess the unique local contribution or responsibility.

\section{Informal Aspects of Responsibility}

We have mapped responsibilities by providing financial statistics. Merely mapping powers and local government access to resources ignores their potential to gain the powers and responsibilities that are not formally granted (Lukes, 1974). Much of this ability comes through informal paths and personal networks. Such political and administrative linkages between central and local levels may promote collaboration and allow local officials and local authorities to assume responsibilities that are beyond their formal remit. As a result, we cannot really compare differences at the levels of government responsibilities because some aspects of this may be intangible.

\section{Reputation vs. Reality}

The perceived levels of local responsibility do not necessarily correspond to actual levels. The countries proud of their historically strong local authorities may in fact be found to severely restrict local autonomy while upholding a traditional image of being a decentralised state. Outsiders' perceptions may also be misinformed due to 
visible markers such as formally constituted laws and regulations. These visible markers may determine the view outsiders have of local authorities in a country. Other countries, for instance, may perceive English local governments as having substantial responsibilities because of their budgets, staff numbers, and population size. The presence of directly elected or otherwise powerful mayors may be such a symbol in other countries.

\subsection{What Do Citizen Demands Actually Mean?}

When asked whether they considered increasing the power of local authorities to be a good thing, citizens express an opinion. This opinion is based on perceptions of local and central government, and on the perceptions of the way in which government levels exercise the responsibilities that they already have. Unlike comparative local government research, these opinions are unlikely to be based on the citizens' comparative analysis of the situation in their country and abroad. It is also likely that their perceptions are based on the general and political discourse about local government, and on the above-mentioned visible symbols of local government power (or the absence thereof). In this paper, the comparison is thus based on the perceived power of local government. Citizens may thus be in favour of assigning an increased responsibility to local authorities, while in fact local authorities may already be quite powerful in their country, and there may be a few areas in which local government does not yet exercise competency.

Therefore, even if we were able to objectively compare the different responsibilities of local government in Europe, we would not know how they are actually perceived by citizens. In the countries with strong local government, citizens may perceive the local level as weak with a limited responsibility. In other countries, citizens may think local government has a great many responsibilities, while it may, in fact, have hardly any discretion in budgetary or decision-making issues. This absence of data suggests that in the future citizen surveys across Europe, efforts should be made to include some measures for understanding the functions that local government is expected to fulfil. This would allow more accurate assessments of how local government is perceived in Europe.

In the previous section, Figure 4 suggests a possible explanation for the absence of a relation between the actual responsibilities of local government and the citizen support for increasing them. It shows a correlation between local government expenditure as a percentage of the GDP and support for increased local government responsibility, but this correlation disappears when the Central and Eastern European countries are dropped from the analysis. Citizens' attitudes towards government are generally more negative in these countries than in Western European countries (Mishler \& Rose, 1999). Rather than being a conscious choice for the transfer of responsibilities to the local level, the survey answers reflect distrust towards (central) government. This distrust of central government is likely to have its roots in the experience of the communist dictatorship. In the communist 
system there was a dual subordination system (Bennett, 1993: 43) in which the centralised bureaucracy and the Communist party managed virtually every aspect of the society. As such, local government may be seen as a preferable alternative to centralised authority. Being in favour of increasing the responsibilities of local authorities is a reaction against government by taking away power from government, rather than positively granting it to the local level. In earlier research on citizen attitudes towards government, we have found that citizens tend to adapt opinions on the specific elements of government to their more general mental schema of the concept of 'government'. Whether local authorities should get more power is quite a complex question for most citizens, and in answering this question, citizens will tap from more easily accessible information about government or power in general (Zaller, 1996). In a similar way, citizens may tap from a wider set of conceptions of local government. These views may be informed by an ideology (King, 1995).

These opinions may also be informed by their own direct experience with local government. Rather than considering the local level as a heaven or training ground for democracy (Lowndes, 1995; Vetter, 2007), and as being close to the people, in some countries, citizens may consider their local government to be too close to the people. In such cases, local government may be thought of as a hotbed of petty corruption and nepotism. Furthermore, as a result of this closeness and related small scale, local governments may, in some cases, be considered as inefficient and ineffective. Again, however, opinions on the occurrence of corruption at the local level, or about small local government inefficiency, may be found to be influenced not by actual corruption levels or inefficiencies, but by a broadly accepted national debate about local government. In this respect, there are some interesting calls in England for increasing the size of local government because of its in ability to achieve economies of scale, while the size of the average English local government is already larger than anywhere else in Europe.

\subsection{Measurement and Comparative Local Government}

The financial data used in this paper are rather old, but these pieces of information are still the most recent and authoritative sources. Despite the fact that the Council of Europe publication we use was published in 2000, most of the financial data in the report refers to the situation in the early or mid-1990s. This makes the data for some countries more than 10 years old. There appears to be a real lack of reliable recent data both on financial issues and other local government-related topics. Local government responsibilities are dynamic with centripetal or centralising tendencies in some countries. But on the other hand, the local level is getting more autonomy elsewhere. These centripetal and centrifugal evolutions make the absence of recent data all the more problematic. 
The reason for this deficiency may be the limited amount of scholarship that has conducted systematic comparisons between local governments in different countries. In terms of structures, we often have to rely on older materials, or on the material prepared by the Council of Europe, or on the Committee of the Regions fact sheets. Recent macro-level studies are scarce, with some exceptions (Vetter, 2007; Baldersheim \& Wollmann, 2006; Loughlin, 2001; John, 2001). Recent studies often tend to focus on the specific aspects of local government such as chief executives (Dahler-Larsen, 2002), mayors (Bäck et al., 2006), or local politics (Szücs and Strömberg, 2006; Delwit et al., 2007), or they focus on recent reforms and changes in local government (Proeller, 2006; Denters and Rose, 2005; Kersting and Vetter, 2003; Wollmann, 2004). Some more general studies focus on a geographically limited set of countries (Lankina et al., 2008; Coulson and Campbell, 2008; Baldersheim et al., 2003), or on a limited number of major countries (DiGaetano, 2002). Comparing local government is not straightforward because of the enormous task and a long list of criteria that could be used in the comparison, and because of institutional complexity and important differences between different local governments within countries (Stoker, 2006). Therefore, such a project needs a coordinated and integrated approach with multi-national collaboration.

\subsection{Future Research Agenda}

This paper addresses the question of whether or not European citizens actually want local government to be granted more responsibilities. However, due to empirical data limitations, the paper is unable to compare different functions of local government across Europe. This is an important limitation in the research because it is possible that some citizens of Western European countries do not want to see local government granted more responsibilities across a broad spectrum, but they would be happy to see local government given more responsibilities over specific areas. Therefore, future research into subsidiarity should attempt to gather more precise information on the specific responsibilities that citizens wish to see exercised by local government or how they view the performance of local government. The collection of such data would be expensive, difficult and timeconsuming because the researcher would be faced with the task of identifying different functions of local government that should or could be compared across different countries. It is the contention of the authors that such data is worth collecting and that the difficulties are not insurmountable. The data collection that relates citizen perceptions to specific local government functions would allow comparative political research to achieve a greater depth. The data will allow policy-makers to devolve responsibilities to local government based upon an accurate understanding of what has been actually demanded by the citizens of a country. Furthermore, the collection of attitudinal data on the specific functions of local government could be linked to extensive data on local government performance available in most countries (Denters \& Rose, 2005; Lankina et al., 2008; Stegarescu, 2005). This may offer a means of enhancing the measures of local 
government performance by using richer instruments that are able to view performance as something more than mere calculations of economic efficiency. We hope that the issues raised in this paper will contribute to such an exercise.

\section{Conclusion}

The transfer of responsibility from central government to the local level is increasingly seen as vital to the functioning of democracy in Europe. This is justified both on economic grounds as being more efficient and on the grounds of democratic legitimacy because the local level is seen as being more responsive to the concerns of citizens (Vetter, 2007). However, it has not been established whether this transfer of power is significant, or whether it is even desired. The paper deals with these questions by examining the levels of responsibility afforded to local government, and thereby ascertaining whether or not citizens actually want the responsibilities of local government to be increased.

By using financial data as a proxy variable to measure local government activities, it has been found that it is possible to identify broad groups of 'northern' and 'southern' countries. These groupings are not particularly strong, and it would be inaccurate to conclude that these countries have much in common with each other. However, the fact that the observed cluster mirrors the ones of Page/Goldsmith (1987) and Hesse/Sharpe (1991) suggests that these established frameworks have validity as a heuristic device. Although the frameworks do have some use as a heuristic (John, 2001), there remains the need for further investigation into the competencies and responsibilities of local government. This would also provide scholars with up-to-date data, and it would free comparative research from relying on data collected more than 10 years ago.

The paper also examines whether there is demand among European citizens for increasing the responsibilities of local government. It has been found out that the overall picture is mixed. The most important finding, however, is that of an absence of a clear and strong relation between the responsibilities local government in a country and the demands of citizenry for granting more or fewer responsibilities to the local level. This finding has been used to reflect on present comparative local government research. It suggests the need for progress in two areas: one is performance measurement in local government and the other one is the desirability of more international comparative opinion research that focuses on the local level rather than on the central level. 


\section{Acknowledgements}

Part of this paper is based on work carried out for the Economic and Social Research Council's Knowledge Transfer Team, and the authors thank the ESRC for funding the project.

\section{References}

Almond, G. A. \& Verba, S. (1965) The civic culture: political attitudes and democracy in five nations (Princeton, NJ: Princeton University Press).

Baldersheim, H., Illner, M. \& Wollmann, H. (2003) Local democracy in post-communist Europe (Wiesbaden: VS Verlag).

Baldersheim, H. \& Wollmann, H. (2006) Comparative Study of Local Government and Politics: Overview and Synthesis (Opladen: Barbara Budrich Publishers).

Bäck, H., Heinelt, H. \& Magnier, A. (2006) The European mayor: Political leaders in the changing context of local democracy (Wiesbaden: VS Verlag).

Bennett, R. J. (1993) European Local Government Systems, In: Bennett, R.J. (ed.) Local Government in the New Europe (London: Belhaven Press).

Blair, P. (1991) Trends in Local Autonomy and Democracy: Reflections from a European Perspective, In: Batley, R. and Stoker, G. (eds.) Local Government in Western Europe, pp. 41-57 (Basingstoke: Palgrave Macmillan).

Borraz, O. \& Le Galès, P. (2005) France: the Intermunicipal Revolution, In: Denters, B. and Rose, L. E. (eds) Comparing Local Governance, pp. 12-28 (Basingstoke: Palgrave Macmillan).

Brans, M. (1992) Theories of local government reorganization: An empirical evaluation, Public Administration,70(3), pp. 429-451, doi:10.1111/j.1467-9299.1992.tb00948.x.

Coulson, A. \& Campbell, A. (2008) Local government in Central and Eastern Europe: The rebirth of local democracy (London: Routledge).

Council of Europe (1985) European Charter of Local Self-Government, Strasbourg.

Council of Europe (2000) The financial resources of local authorities in relation to their responsibilities: a litmus test for subsidiarity. 4th General Report on Political Monitoring of the Implementation of the European Charter of Local Self-Government.

Dahler-Larsen, P. (2002) Social bonds to the city hall (Odense: Odense University Press).

Delwit, P., Pilet, J.-B., Reynaert, H., \& Steyvers, K. (2007) Towards DIY-politics? Participatory and direct democracy at the local level in Europe (Brugge: Vanden Broele).

Denters, B., \& Rose, L. E. (2005a) Local Governance in the Third Millennium: a brave new world?, In: Denters, B. \& Rose, L.E. (eds) Comparing local governance: trends and developments, pp. 1-11 (Basingstoke: Palgrave Macmillan).

Denters, B., \& Rose, L. E. (2005b) Towards Local Governance, In: Denters, B. \& Rose, L. E. (eds) Comparing local governance: trends and developments, pp. 246-262 (Basingstoke: Palgrave Macmillan).

DiGaetano A. (2002) The changing nature of the local state: a comparative perspective, Policy \& Politics, 30(1), pp. 61-77.

Elander, I. (1991) Analysing Central-Local Government Relations in Different Systems: A Conceptual Framework and Some Empirical Illustrations, Scandinavian Political Studies, 14(1), pp. 31 - 58, doi:10.1111/j.1467-9477.1991.tb00404.x. 
Goldsmith, M. (2005) A new intergovernmentalism?, In: Denters, B. \& Rose, L. E. (eds.) Comparing local governance: trends and developments, pp. 228-245 (Basingstoke: Palgrave Macmillan).

Halman, L. (2001) The European Values Study: A third wave: source book of the 19992000 European Values Study surveys (Tilburg: WORC, Tilburg University).

Haveri, A (2006) Complexity in Local Government Change: Limits to Rational Reforming, Public Management Review, 8(1) pp. 31-46, doi:10.1080/14719030500518667.

Hesse, J. J. \& Sharpe, L. J. (1991) Local Government in International Perspective - some comparative observations, In: Hesse, J. (ed.) Local Government and Urban Affairs in International Perspective. Analysis of 20 Western Industrialised Countries (BadenBaden: Nomos Verlagsgesellschaft).

Hulst, R., \& van Montfort, A. (2007) Inter-municipal cooperation in Europe (Dordrecht: Springer Netherlands).

Inglehart, R. (1997) Modernization and postmodernization: cultural, economic and political change in 43 societies (Princeton: Princeton University Press).

John, P. (2001) Local Governance in Western Europe (London: Sage).

Kersting, N. \& Vetter, A. (2003) Reforming local government in Europe: Closing the gap between democracy and efficiency (Wiesbaden: VS Verlag).

Kjellberg, F. (1985) Local government reorganization and the development of the welfare state. Journal of Public Policy, 5(2), pp. 215-239, doi: 10.1017/S0143814X00003032.

Kjellberg, F. (1995) The Changing Values of Local Government, The Annuals of the American Academy of Political and Social Science, 540(1), pp. 40-51, doi: $10.1177 / 0002716295540000004$.

King, D. (1995) From the urban left to the new right: Normative theory and local government, In: Stewart, J. \& Stoker, G. (eds.) Local government in the 1990s, pp. 228248 (London: Palgrave Macmillan).

Kuhlmann, S. (2006) Local Government Reform Between 'Exogenous' and 'Endogenous' driving forces: Institution building in the City of Paris, Public Management Review, 8(1), pp. 67-88, doi: 10.1080/14719030500518790.

Lankina, T. V., Hudalla, A., \& Wollmann, H. (2008) Local governance in Central and Eastern Europe: Comparing performance in the Czech Republic, Hungary, Poland, and Russia (Basingstoke: Palgrave Macmillan).

Lidström, A. (1998) The comparative study of local government: a research agenda, Journal of Comparative Policy Analysis, 1(1), pp. 95-115, doi: 10.1080/13876989808412617.

Loughlin, J. (2001) Subnational democracy in the European Union (Oxford: Oxford University Press).

Lowndes, V. (1995) Citizenship and urban politics, In: Judge, D., Stoker, G \& Wolman, H. (eds) Theories of urban politics, pp. 160-180 (London: Sage).

Lukes, S. (1974) Power: A Radical View (London: Macmillan).

Mishler, W., \& Rose, R. (1999) Five years after the fall: trajectories of support for democracy in post-communist Europe, In: Norris, P. (ed.) Critical citizens: global support for democratic governance, pp. 78-99 (Oxford: Oxford University Press).

Norton, A. (1991) Western European Local Government in Comparative Perspective, In: Batley, R. \& Stoker, G. (eds) Local Government in Western Europe, pp. 21-41 (Basingstoke: Macmillan Education).

Norton A. (1993) International Handbook of Local and Regional Government: A Comparative Analysis of Advanced Democracies (Aldershot: Edward Elgar).

Oates, W. (1972) Fiscal Federalism (New York: Harcourt Brace). 
Page, E. C. \& Goldsmith, M. (1987) Centre and Locality: functions, access and discretion, In: Page, E. C. \& Goldsmith, M. J. (eds) Central and Local Government Relations, pp. 1-12 (London: Sage).

Page, E. (1991) Localism and Centralism in Europe (Oxford: Oxford University Press).

Pollitt, C. (2003) The Essential Public Manager (Maidenhead: Open University Press).

Proeller, I. (2006) Trends in Local Government in Europe, Public Management Review, 8(1) pp. 7-31, doi: 10.1080/14719030500518642.

Reigner, H. (2001) Multi-level governance or co-administration? Transformation and continuity in French local government, Policy \& Politics, 29(2), pp. 181-192.

Sharpe, L. J. (1970) Theories and values of local government, Political Studies, 18(2), pp. 153-174, doi: 10.1111/j.1467-9248.1970.tb00867.x.

Sharpe, L. J. (1988) The Growth and Decentralisation of the Modern Democratic State, European Journal of Political Research, 16(4), pp. 365-380, doi: 10.1111/j.14756765.1988.tb00158.x.

Stegarescu, D. (2005) Public sector decentralisation: measurement concepts and recent international trends, Fiscal Studies, 26(3), pp. 301-333, doi: 10.1111/j.14755890.2005.00014.x.

Stoker, G. (2006) The Comparative Study of Local Governance: the need to go global (Unpublished Conference Paper, Presented at the Hallsworth Conference, University of Manchester, UK, 17-18 March 2006).

Szücs, S., \& Strömberg, L. (2006) Local elites, political capital and democratic development: Governing leaders in seven European countries (Wiesbaden: VS Verlag).

Tiebout, C.M. (1956) A pure theory of local expenditures, Journal of Political Economy, 64(5), pp. 416-424, doi: 10.1086/257839.

Vetter, A. (2002) Local Political Competence in Europe: A resource of legitimacy for higher levels of government? International Journal of Public Opinion Research, 14(1), pp. 3-18.

Vetter, A. (2007) Local politics: A resource for democracy in Western Europe? Local autonomy, local integrative capacity, and citizens' attitudes toward politics (Lanham, MD: Lexington Books).

Wayenberg, E. (2006) The Flemish government's responsibility for local government modernization. Public Management Review, 8(1), pp. 47-65, doi: 10.1080/14719030500518741.

Wollmann, H. (2000) Local government systems: from historical divergence towards convergence? Great Britain, France, and Germany as comparative cases in point, Environment and Planning C: Government and Policy, 18(1), pp. 33-55, doi: $10.1068 / \mathrm{c} 9867$.

Wolman, H. (1990) Decentralization: What it is and why we should care, In: Bennett, R. J. (ed.) Decentralization, local governments and markets: Towards a post-welfare agenda, pp. 29-42 (Oxford: Clarendon Press).

Wolman, H. (1995) Local government institutions and democratic governance, In: Judge, D., Stoker, G. \& Wolman, H. (eds) Theories of urban politics, pp. 135-159 (London: Sage).

Wolman, H. (2008) Comparing local government systems across countries: conceptual and methodological challenges to building a field of comparative local government studies, Environment and Planning C: Government and Policy, 26(1), pp. 87-103, doi: $10.1068 /$ cav5.

Zaller, J. (1996) The nature and origins of mass opinion (Cambridge: Cambridge University Press). 